\title{
Anti-fertility and antisteroidogenic activity of Clerodendrum serratum in mature male rats
}

\author{
Navaneetha Krishnan Subramaniyan ${ }^{1}$ (D), Nagarajan Govinda Rajan² (D), Karthikeyan Elumalai ${ }^{3}$ (D), \\ Sathyanathan Viswanathan ${ }^{4}$ (D), Jayaraman Rajangam ${ }^{1}$ (D), Preeti Gutha ${ }^{1}$ (D), Sivaneswari Srinivasan ${ }^{5}$ (i) \\ 'Dr. Kalam College of Pharmacy, Thanjavur District-613624, Tamil Nadu, India \\ ${ }^{2}$ Dr. K.V Subbareddy Institute of Pharmacy, Department of Pharmacology, Andhra Pradesh, India \\ ${ }^{3}$ Vels Institute of Science, Technology and Advanced Studies, School of Pharmaceutical Sciences, Department of Medicinal \\ Chemistry, Chennai, India \\ ${ }^{4}$ Apollo College of Pharmacy, Department of Pharmacognosy, Tamil Nadu, India \\ ${ }^{5}$ Department of Pharmaceutics, KK College of Pharmacy, Gerugambakkam, Chennai, India
}

ORCID IDs of the authors: N.K.S. 0000-0002-2450-3062; N.G.R. 0000-0002-0143-5502; K.E. 0000-0002-6259-5332;

S.V. 0000-0002-0143-5544; J.R. 0000-0002-6367-0365; P.G. 0000-0002-4737-7898; S.S. 0000-0002-1630-9040

Cite this article as: Subramaniyan, N. K., Rajan, N. G., Elumalai, K., Viswinathan, S., Rajangam, J., Gutha, P. ... Sirinivasan, S. (2021). Anti-fertility and antisteroidogenic activity of Clerodendrum serratum in mature male rats. Istanbul Journal of Pharmacy, 51(2), 212-220.

\begin{abstract}
Background and Aims: The study was designed to evaluate the anti-fertility effect of methanolic extract of Clerodendrum serratum (MECS) on mature male rats.

Methods: The vehicles and MECS were administered orally to four groups of forty male albino rats on consecutive days for 30 days. At the end of the experimental period, five animals from both the control and experimental groups were given anesthesia and the animal reproductive organs were collected and anti-fertility effect evaluated by studying the following parameters (i) Body and reproductive organ weight (ii) Biochemical estimation (iii) Reproductive hormone analysis (iv) Abnormalities in reproductive organ histology. Another five rats in each group were subjected to fertility testing.

Results: This study shows that female rats which mated with MECS treated male rats delivered fewer pups than those which mated with the control rats. An antisteroidogenic effect was revealed through the increased concentration of testicular cholesterol and ascorbic acid in MECS treated rats. However, testicular $\Delta^{5}$ - $3 \beta$-hydroxysteroid dehydrogenase $\left(\Delta^{5}-3 \beta-H S D\right)$, glucose-6-phosphate dehydrogenase (G-6-PD); serum reproductive hormones testosterone, FSH and LH were significantly reduced.

Conclusion: The present investigation discovered the antisteroidogenic effect of MECS, which confirms the male antifertility effect of this plant. This encourages the traditional use of this plant in the Indian subcontinent as a male contraceptive.

Keywords: Clerodendrum serratum, $\Delta^{5}-3 \beta$-hydroxysteroid dehydrogenase ( $\Delta^{5}-3 \beta$-HSD), glucose-6-phosphate dehydrogenase (G-6-PD), reproductive hormones
\end{abstract}

\section{INTRODUCTION}

The population of India is increasing at an alarming rate and has gone above 1.5 billion. Regulation of fertility has become a major distress factor for many people (Savadi \& Alagawadi, 2009). A growing population is not only a worldwide issue but also a national public well-being concern. Birth control mea- sures have become an essential part of our live. There are limited contraceptive agents available for men and these are only to be found in the market. However, women have access to various synthetic contraceptive agents, but these come with severe side effects (Joshi, Sharma \& Chaturvedi, 2011). The WHO recommended the practice of utilization of traditional 
medicine for conception prevention instead of using synthetic drugs as this is more cost-effective (Umadevi Kumar, Bhowmik, \& Duraivel 2013).

Clerodendrum serratum (L.) Moon (Verbenaceae) is a vital medicinal plant distributed throughout the tropical forest region in India and Sri Lanka and other warm temperature regions like South Asia, Malaysia and Africa. In the Indian system of medicine, C. serratum is an important medicinal plant and its leaves and roots are used for various ailments. C. serratum (English: Blue-floral glory, Tamil: Cherutekku) leaves can be used as a febrifuge and the roots are used as antiasthmatic, antihistaminic, antispasmodic, antitussive carminative and febrifuge (Khare, 2007). The 50\% ethanolic extract of C. serratum demonstrated in vitro spermicidal activity in rat and human semen. A N-butanol fraction of $50 \%$ ethanolic C. serratum extracts also exhibited in vitro spermicidal activity in humans (Setty Kamboj, \& Khanna 1977). As per our earlier research this plant shows changes in sperm concentration and motility with abnormalities in sperm morphology indicating that the plants have a potential spermatotoxic effect on male mature rats. C. serratum is a traditional tribal folk medicine which works as a male contraceptive (Pokharkar, Saraswat, \& Kotkar, 2010).

The major groups of chemical constituents present in the $C$. serratum are carbohydrates, serratagenic acid, acteoside, indolizino and verbascoside, leucoanthocyanidins, flavanones, flavanonols, betulin, oleanolic acid, clerodermic acid $\beta$-sitosterol, $\gamma$-sitosterol and compesterol (Singh, Khare, lyer, \& Tripathi, 2012).

Nevertheless, scientific evidence about the potential effects of this plant on male antifertility effect is still lacking. In this study, we sought to extend the existing literature dealing with the investigation of the anti steroidogenic effect of $C$. serratum in male mature rats. The present work, therefore, attempts to report the preliminary results based on our in vivo studies to justify traditional and folklore beliefs.

\section{MATERIALS AND METHODS}

\section{Animals}

We utilized 40 Sprague-Dawley rats which weight ranged from 150 to $200 \mathrm{~g}$. The rats were kept in certain conditions including a $12 \mathrm{~h}$ dark $/ 12 \mathrm{~h}$ light cycle with free running water and pellets of rat feed. They were kept in relative humidity of $55 \pm 10 \%$ and constant temperature $\left(21 \pm 2^{\circ} \mathrm{C}\right)$. All the animals were prepared for acclimatization for half a month. The experimental protocols were assessed and agreed by the Institutional Animal Ethics Committee (IAEC) of the institute (No. SRCP/IAEC/B.Pharm. Project /01 /2016-17).

\section{Preparation of extract}

The aerial parts of C. serratum were collected from the eastern part of the Seshachalam hill ranges and from the area lying within the geographical coordinates $14.3333^{\circ} \mathrm{N}, 78.2500^{\circ} \mathrm{E}$ in Thirumala, Andhra Pradesh, India. Taxonomical identification was made using the Botanical Survey of Medicinal Plants Unit at Sri Venkateshwara University, Thirupathi, Andhra Pradesh, India in August 2012. Figure 1 shows the aerial parts of the plant which were used for this study (Singh et al., 2012).

The aerial parts of C. serratum were dried at $28^{\circ} \mathrm{C}$, pulverized by a mechanical grinder and passed through 22 mesh sieves. The powder was subjected to defatting with petroleum ether (40$60^{\circ} \mathrm{C}$ ), followed by Soxhlet extraction with $70 \% \mathrm{v} / \mathrm{v}$ ethanol at $68^{\circ} \mathrm{C}$. The extracts were collected and filtered. The solvent was dried under reduced pressure using the Eyela Rotary evaporator at $40-45^{\circ} \mathrm{C}$. Finally, the crude extract was stored in vacuum desiccators. Based on our survey of the literature, we chose methanol solvent to extract the following active components from this plant: terpenoids, saponins, tannins, xanthoxyllines, totarol, quassinoids, lactones, flavones, phenones, and polyphenols (Pandey \& Tripathi, 2014).

\section{Design of the experiments}

The Sprague-Dawley rats were housed and acclimatized for one week before the experiment started. Forty healthy male albino rats were selected and divided into four groups containing 10 rats each and treated as follows:

Group 1 received distilled water (10 $\mathrm{mL} \mathrm{kg}^{-1}$ b.wt. p.o.) as the normal control; Group 2 received MECS (100 $\mathrm{mg} \mathrm{kg}^{-1}$ b.wt. p.o.); Groups 3 and 4 received MECS at doses of 300 and $500 \mathrm{mg} \mathrm{kg}^{-1}$ b.wt p.o.), respectively.

The vehicles and MECS were administered orally on 30 consecutive days. At the end of the experimental period, five animals from both the control and experimental groups were given anesthesia under sodium pentobarbital $24 \mathrm{~h}$ after the last dose

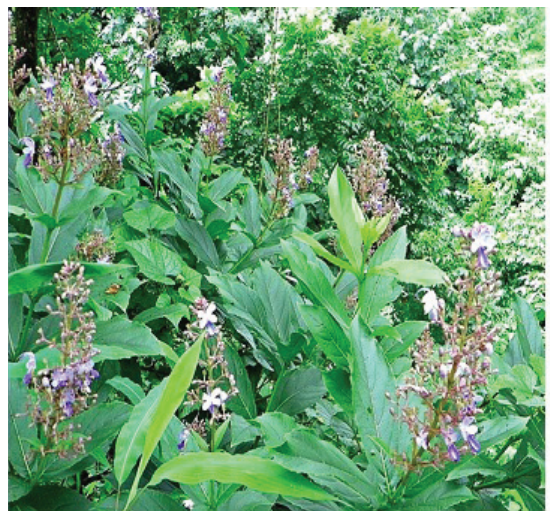

\begin{tabular}{|c|c|}
\hline $\begin{array}{l}\text { Botany } \\
\text { The taxonomic }\end{array}$ & al position is as follow s: ${ }^{6}$ \\
\hline Kingdom: & Plantae \\
\hline Sub-kingdom: & Viridaeplantae \\
\hline Division: & Angiospermae \\
\hline Class: & Magnoliopsida \\
\hline Subclass: & Lamiidae \\
\hline Order: & Lamiales \\
\hline Family: & Lamiaceae/Verbenaceae \\
\hline Genus: & Clerodendrum \\
\hline pecies: & serratum \\
\hline
\end{tabular}

Figure 1. Aerial parts of the C. serratum. 
and $18 \mathrm{~h}$ after fasting. The animal reproductive organs were utilized for histology studies, including measurement of reproductive organ weight, biochemical estimation, and reproductive hormone analysis. Another five rats in each group were subjected to fertility testing.

\section{Gravimetric analysis of body weight and weights of re- productive organs}

The body weights of the animals were recorded prior to and after treatment. Testis, epididymis, and seminal vesicles were weighed. Relative organ weight (ROW) for each organ collected was ascertained using the following expression:

\section{Determination of reproductive performance}

Every animal's fertility index was calculated as follows. After completion of teatment schdule, each male animal was paired with two fertile females, and their mating behavior was observed. Samples from vaginal smears were analyzed the day after the mating exposure. Day 0 post coitum was considered if spermatozoa were present. On the $15^{\text {th }}$ post-coitum day, the mated females were laparotomized, the resorption site and/ or several implantations were registered, and the term was allowed to run its course. The number of females who gave birth, as well as the number of litters born, was also reported (WHO Protocol MB-50, 1983).

\section{Biochemical estimations Estimation of cholesterol}

An approximate weight of 3 mg of testicular tissues was carefully homogenized in Potter-Elvejem homogenizer using the combination of chloroform: ethanol mixture (2:1), non-polar parts were extracted out, and then the total cholesterol content was estimated. A standard curve was prepared by dissolving cholesterol $(0.1,0.2,0.3,0.4,0.5$, and $0.6 \mathrm{mg} / \mathrm{mL})$ in chloroform, mixed with glacial acetic acid and color reagent accordingly. The optical density was determined in the spectrophotometer at $620 \mathrm{~nm}$ against a blank (chloroform) and the total cholesterol content of the testis was determined from the standard curve (Speery \& Webb, 1950).

\section{Estimation of ascorbic acid}

Testicular tissues weighing around $5 \mathrm{mg}$ were homogenized in a Potter-Elvejem homogenizer with $45 \mu \mathrm{L}$ of ice-cold 5\% metaphosphoric acid and centrifuged at $3500 \mathrm{rpm}$. The optical density was estimated at $540 \mathrm{~nm}$ using $30 \mu \mathrm{L}$ of supernatant and $15 \mu \mathrm{L}$ of 2.6-dichlorophenol-indophenol sodium $(0.1 \mathrm{mg} / \mathrm{mL})$. The standard curve was drawn against the established ascorbic acid concentration. The standard curve was used to calculate the amount of ascorbic acid present in the testis (Omaye, Turnbull, \& Souberlich, 1979).

\section{Estimation of Glucose-6-Phosphate Dehydrogenase (G- 6-PD) activity}

Testes were homogenized and the mixture was centrifuged at $1000 \mathrm{~g}$ for 5 minutes at $0^{\circ} \mathrm{C}$, the supernatant was again centrifuged at $10,000 \mathrm{~g}$ for 10 minutes at $0^{\circ} \mathrm{C}$. $0.2 \mathrm{~mL}$ of Tris $\mathrm{HCl}$ buffer ( $\mathrm{pH} 8.3,0.5 \mathrm{M}), 0.01 \mathrm{~mL}$ of $20 \mathrm{mM}$ Nicotinamide adeninen dinucleotide phosphate (NADP), $0.025 \mathrm{~mL}$ of tissue extract and $0.025 \mathrm{~mL}$ of glass distilled water were added and mixed well. The absorbance of this mixture was read was kept in a spectro- photometer at $340 \mathrm{~nm}$ against a blank (distilled water) (Lohr \& Waller, 1974)

\section{Estimation of $\Delta^{5}-3 \beta$-Hydroxysteroid Dehydrogenase ( $\Delta^{5}$ - $3 \beta$ - HSD) activity}

The weighed testes were homogenized in $0.1 \mathrm{M}$ phosphate buffer ( $\mathrm{pH} 7.4$ ) and centrifuged at $10000 \times \mathrm{g}$. for 10 minutes at $0^{\circ} \mathrm{C}$. Then the supernatant was taken in a conical flask $(50 \mathrm{~mL})$ and $0.2 \mathrm{~mL}$ of Nicotinamide adenine dinucleotide (NAD), 0.1 $\mathrm{mL}$ of dehydroepiandrosterone were added and mixed well. This solution was kept in a shaking incubator at $37^{\circ} \mathrm{C}$ for 90 minutes, and acidified with $0.1 \mathrm{~mL}$ of $3 \mathrm{M}$ acetate buffer $(\mathrm{pH}$ 5.0). This solution was then extracted with $10 \mathrm{~mL}$ of ethyl acetate and evaporated until it was dry. The residue was dissolved in $2 \mathrm{~mL}$ of ethanol and optical density was read by a spectrophotometer at $240 \mathrm{~nm}$ against ethanol as the blank. The protein content of the tissue was determined and specific activity was expressed per mg of protein (Rabin, Leipsner, \& Deane, 1961).

\section{Estimation of Follicle Stimulating Hormone (FSH), Lu- teinizing Hormone (LH) and Testosterone}

Serum FSH, LH, and testosterone levels were assessed using an enzyme-linked immunosorbent assay kit from UNITED BIOTEK, Canada. In 96 well plates, $50 \mu \mathrm{L}$ rabbit anti-hormone reagent, $100 \mu \mathrm{L}$ of working hormone-HRP conjugate reagent, and 25 $\mu \mathrm{L}$ standard and samples, were added to each well and incubated at $37^{\circ} \mathrm{C}$ for $1 \frac{1}{2}$ hours. The wells were rinsed five times with distilled water, followed by the addition of $100 \mu \mathrm{L} \mathrm{TMB}$ and incubated at room temperature. The solution $1 \mathrm{~N} \mathrm{HCl}$ was used to stop the reaction. Absorbance was measured at 450 nm (Auletta, Caldwell, \& Hamilton, 1979).

\section{Estimation of fructose in seminal vesicles and epididy- mal protein content}

Fructose content in seminal vesicles was measured using the previously described procedure in keeping with the WHO laboratory manual (Padashetty \& Mishra, 2007). Standard curve was prepared by dissolving fructose $(0.1,0.2,0.3,0.4,0.5$, and $0.6 \mathrm{mM} / \mathrm{mL}$ ) in water and mixing it with indole reagent. Finally, the absorbance was noted at $470 \mathrm{~nm}$ wavelength against blank. Protein was estimated with Folin's phenol reagent and the activities of the enzyme were expressed in unit per mg of protein as per the previously described method (Lowry, Rosenbrough, Farm, \& Randall, 1951). Standard curve was prepared by dissolving BSA $(0.1,0.2,0.3,0.4$, and $0.5 \mathrm{mg} / \mathrm{mL})$ in distilled water. Optical density was recorded at $660 \mathrm{~nm}$ against the reagent blank

\section{Histological studies of rat testis and epididymis}

The histology of the tissue was studied adopting the routine paraffin method (Hamilton, 1975) and resin embedding method (Hayat, 1981). A section of tissue was mounted over the slide for the microscopic studies and the following steps were taken.

The reproductive organs were separated from the experimental and control rats, then washed altogether with normal saline, cut to pieces of the desired size and fixed in Bouin's 
liquid fixative promptly after autopsy examination. Fixation continued at room temperature for one day, after which the tissues were transferred into $70 \%$ alcohol. The tissues were then dried out by passing them through ascending grades in alcohol, cleared in a solution of xylene, penetrated with liquid paraffin, and lastly implanted in paraffin wax $\left(58^{\circ} \mathrm{C} \mathrm{MP}\right) .5 \mu \mathrm{m}$ thickness sections were acquired utilizing a rotary microtome (Leica, Germany). The section was stained in Harris' hematoxylin and eosin was, dried out utilizing alcohol, cleared in xylene and mounted using dihydroxyphthalate xylol (DPX). The stained slides images were captured using a research microscope.

\section{Statistical analysis}

The statistical analysis was performed by Graph Pad Prism 5.0 Version (Graph Pad Software, Inc., San Diego, California, USA). All data are presented as mean \pm SEM and comparisons done by one-way ANOVA followed by Tukey's test as a post hoc test. Values were considered significant at $p<0.05$ or less.

\section{RESULTS}

\section{Body weights and reproductive organ weights}

The final body weights of rats of all groups increased markedly when compared with their respective initial body weights and are shown in Table 1. A great decline in the weights of testis, epididymis and seminal vesicle was observed in all treatment groups when compared with Group I animals and this is shown in Table 1. Oral administration of the extract at the dose of $100 \mathrm{mg} \mathrm{kg}^{-1}$ b.wt, and $300 \mathrm{mg} \mathrm{kg}^{-1}$ b.wt showed significant $(p<0.05)$ decrease in testis, epididymis and vas defenses compared with the control. The most significant reduction $(p<0.01)$ of this reproductive organ weight was observed at the dose of $500 \mathrm{mg} \mathrm{kg}^{-1}$ b.wt compared as with control.

\section{Reproductive performance}

The female rats who mated with the MECS 100,300 and 500 $\mathrm{mg} \mathrm{kg}^{-1}$ b.wt. p.o. treated male rats delivered fewer pups than those mated with the control. However, the female rats who mated with MECS $500 \mathrm{mg} \mathrm{kg}^{-1}$ body weight treated male rats, were not delivered of pups. That is, the MECS $500 \mathrm{mg} \mathrm{kg}^{-1}$ body weight showed 0\% fertility, followed by MECS $300 \mathrm{mg} \mathrm{kg}^{-1}$ b.wt. p.o (16.7\%) and MECS $100 \mathrm{mg} \mathrm{kg}^{-1}$ b.wt. p.o (33.3\%), at a tested dose when compared to the control (100\%). These results are shown in Table 2.

\section{Antisteroidogenic property}

In the current study, the decrease in protein concentration by MECS-treated rats can be attributed to a decrease in secretory activity. Figure 2A shows that the methanol extract of the aerial portion of C. serratum significantly increased cholesterol and

Table 1. Effect of MECS on body and reproductive organ weights of Male albino rats.

\begin{tabular}{|c|c|c|c|c|c|}
\hline \multirow{2}{*}{ Groups } & \multicolumn{2}{|c|}{ Body Weights (Grams) } & \multicolumn{3}{|c|}{ Reproductive Organ Weights (\%) } \\
\hline & Initial & Final & Testis & Epididymis & Seminal Vesicles \\
\hline $\begin{array}{l}\text { Group I- Control } \\
\text { DW (10ml kg-1b.wt. p.o.) }\end{array}$ & $171.3 \pm 2.716$ & $211.5 \pm 3.89$ & $0.745 \pm 0.039$ & $1.65 \pm 0.047$ & $3.27 \pm 0.045$ \\
\hline $\begin{array}{c}\text { Group II- } \\
\text { MECS (100mg kg-1b.wt. p.o.) }\end{array}$ & $171.8 \pm 3.55$ & $210.8 \pm 1.30$ & $0.69 \pm 0.022$ & $0.14 \pm 0.025^{\star}$ & $2.67 \pm 0.25^{\star}$ \\
\hline $\begin{array}{c}\text { Group III- } \\
\text { MECS (300mg kg-1b.wt. p.o.) }\end{array}$ & $169.8 \pm 3.21$ & $207.7 \pm 2.53$ & $0.64 \pm 0.013^{*}$ & $0.12 \pm 0.054^{*}$ & $0.22 \pm 0.03^{*}$ \\
\hline $\begin{array}{c}\text { Group IV- } \\
\text { MECS (500mg kg-1b.wt. p.o.) }\end{array}$ & $170.7 \pm 3.52$ & $210.2 \pm 1.74$ & $0.59 \pm 0.020 * \star$ & $0.10 \pm 0.032 * \star$ & $0.17 \pm 0.12^{\star \star}$ \\
\hline
\end{tabular}

Table 2. Effect of MECS on Reproductive Performance by Fertility testing in Female rats after 30 days of treatment.

\begin{tabular}{|c|c|c|c|c|}
\hline Design of treatment & $\begin{array}{l}\text { Number of mated } \\
\text { males/females }\end{array}$ & $\begin{array}{c}\text { Number of females } \\
\text { delivered }\end{array}$ & $\begin{array}{l}\text { Litter size of the } \\
\text { mated female }\end{array}$ & Percent Fertility \\
\hline $\begin{array}{c}\text { Group I- Control } \\
\text { DW (10ml kg-1 b.wt. p.o.) }\end{array}$ & $3 / 6$ & 6 & 59 & 100 \\
\hline $\begin{array}{c}\text { Group II- } \\
\text { MECS (100 } \mathrm{mg} \mathrm{kg}^{-1} \text { b.wt. p.o.) }\end{array}$ & $3 / 6$ & 2 & 8 & 33.3 \\
\hline $\begin{array}{c}\text { Group III- } \\
\text { MECS (300 } \mathrm{mg} \mathrm{kg}^{-1} \text { b.wt. p.o.) }\end{array}$ & $3 / 6$ & 1 & 2 & 16.7 \\
\hline $\begin{array}{c}\text { Group IV- } \\
\text { MECS (500 } \mathrm{mg} \mathrm{kg}^{-1} \text { b.wt. p.o.) }\end{array}$ & $3 / 6$ & 0 & 0 & 0 \\
\hline
\end{tabular}



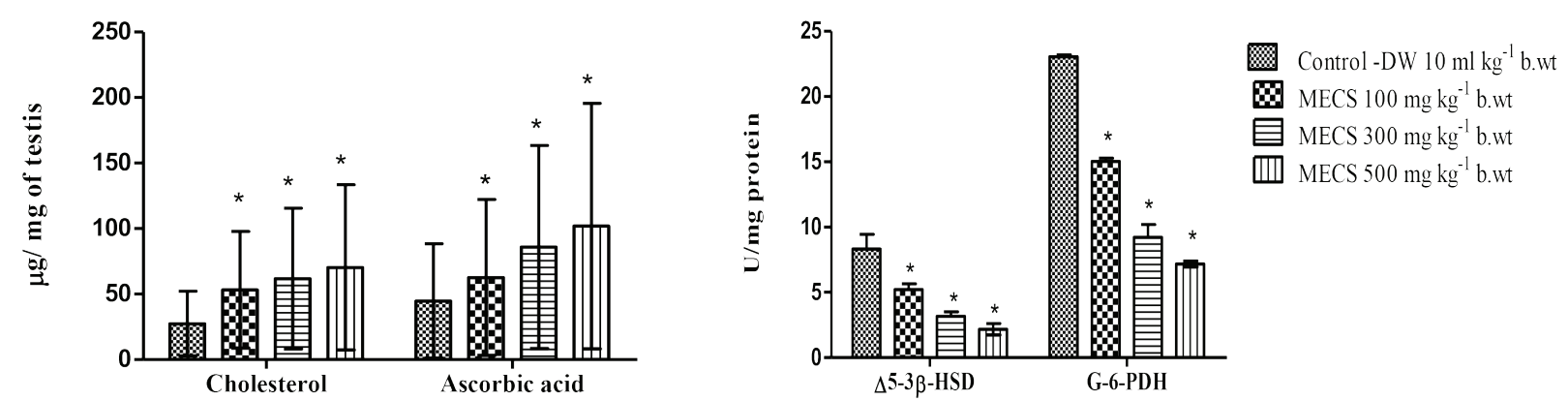

Figure 2. A. Effect of MECS on testicular cholesterol and ascorbic content in male rats after 30 days of treatment. 2. B. Effect of MECS on testicular $\triangle^{5}-3 \beta-H S D$ and G-6-PDH enzymes content in male rats after 30 days of treatment MECS- Methanolic extracts of C. Serratum, DW - Distill water. Data are presented as Mean \pm SEM $(n=5)$; for each dose group. *Mean difference values compared to control group are significant at the 0.05 level.

ascorbic acid content in the testicular tissues of rats at all doses of 100, 300, and $500 \mathrm{mg} \mathrm{kg}^{-1}$ b.wt. When compared to control animals, the MECS $500 \mathrm{mg} \mathrm{kg}^{-1}$ b.wt displayed a significant increase in cholesterol and ascorbic acid content of $133.46 \mathrm{~g} / \mathrm{mg}$ and $195.52 \mathrm{~g} / \mathrm{mg}$, respectively.

The MECS-treatements also suppressed the activities of two primary testicular steroidogenic enzymes, G-6-PD and $5-3 \beta-H S D$, significantly $(p<0.05)$. In Figure $2 B$, the MECStreated rats had the highest suppression of G-6-PD and 5-3 $\beta$ -HSD at $500 \mathrm{mg} \mathrm{kg}^{-1}$ b.wt, with 7.17 and $2.18 \mathrm{U} / \mathrm{mg}$ protein, respectively, as compared to control-treated animals. Among the therapies, this extract demonstrated that this drug has an antisteroidogenic effect in male rats.

Oral administration of the extract at the dose of $100 \mathrm{mg} \mathrm{kg}^{-1}$ b.wt, $300 \mathrm{mg} \mathrm{kg}^{-1}$ b.wt, and $500 \mathrm{mg} \mathrm{kg}^{-1}$ b.wt showed very significant $(p<0.005)$ reduction in serum testosterone, FSH and LH levels comparable to that of the control has shown in Table 3. The results are summarized in Table 4. Among all groups, the MECS $500 \mathrm{mg} \mathrm{kg}^{-1}$ b.wt treated rats showed more of a reduction in the content of fructose in seminal vesicles, and epididymal protein content was $1.5 \%$ and $55.54 \%$, respectively when compared to the control.

Table 3. Effect of MECS on fructose content in seminal vesicle and epididymal protein content of male rats.

\begin{tabular}{|c|c|c|}
\hline Design of treatment & Fructose in seminal vesicle $(\mathrm{mg} / \mathrm{g})$ & Protein in epididymis $(\mathrm{mg} / \mathrm{g})$ \\
\hline $\begin{array}{l}\text { Group I- Control } \\
\text { DW (10ml kg-1 b.wt. p.o.) }\end{array}$ & $4.88 \pm 0.21$ & $237.23 \pm 5.19$ \\
\hline $\begin{array}{c}\text { Group II- } \\
\text { MECS (100 } \mathrm{mg} \mathrm{kg}^{-1} \text { b.wt. p.o.) }\end{array}$ & $3.33 \pm 0.11^{*}$ & $131.08 \pm 3.78^{*}$ \\
\hline $\begin{array}{c}\text { Group III- } \\
\text { MECS (300 } \mathrm{mg} \mathrm{kg}^{-1} \text { b.wt. p.o.) }\end{array}$ & $2.45 \pm 0.11^{*}$ & $77.42 \pm 2.30 *$ \\
\hline $\begin{array}{c}\text { Group IV- } \\
\text { MECS (500 } \mathrm{mg} \mathrm{kg}^{-1} \text { b.wt. p.o.) }\end{array}$ & $1.5 \pm 0.05^{\star}$ & $55.54 \pm 1.47^{*}$ \\
\hline
\end{tabular}

Table 4. Effects of MECS on hormone profile of male albino rats.

\begin{tabular}{|c|c|c|c|}
\hline Groups & Testosterone & LH & FSH \\
\hline $\begin{array}{c}\text { Group I- Control } \\
\text { DW ( } 10 \mathrm{ml} \mathrm{kg}^{-1} \text { b.wt. p.o.) }\end{array}$ & $5.160 \pm 0.025$ & $4.470 \pm 0.560$ & $3.397 \pm 0.352$ \\
\hline $\begin{array}{c}\text { Group II- } \\
\text { MECS (100 } \mathrm{mg} \mathrm{kg}^{-1} \text { b.wt. p.o.) }\end{array}$ & $3.367 \pm 0.465^{\star}$ & $2.310 \pm 0.223^{*}$ & $1.990 \pm 0.054^{*}$ \\
\hline $\begin{array}{c}\text { Group III- } \\
\text { MECS (300 } \mathrm{mg} \mathrm{kg}^{-1} \text { b.wt. p.o.) }\end{array}$ & $2.087 \pm 0.094^{* *}$ & $2.087 \pm 0.076$ ** & $1.950 \pm 0.043^{\star *}$ \\
\hline $\begin{array}{c}\text { Group IV- } \\
\text { MECS (500 } \mathrm{mg} \mathrm{kg}^{-1} \text { b.wt. p.o.) }\end{array}$ & $1.612 \pm 0.063^{\star * *}$ & $1.680 \pm 0.329$ *** & $1.180 \pm 0.043^{* * *}$ \\
\hline
\end{tabular}




\section{Effects of MECS on tissue histology}

\section{Testicular histology}

As shown in Figure 3, the histological results indicated that the control animals had the usual histological structure of rat testis. Standard seminiferous tubules with multiple germ cells are visible in this segment. There is evidence of spermatogenesis, as shown by the orderly maturation of germ cells from the lumen's base to its middle. In MECS-treated testes (Sections B, C, and D), there were fewer secondary spermatocytes, spermatids, and Leydig cells, as well as histological damage to the testes with an increased diameter of seminiferous tubules, there are areas of degenerating cells and debris.

\section{Epididymis histology}

The findings revealed that the control animal had typical histological structure of the rat epididymis. Figure 4, Section A of the control epididymis reveals multiple tubules lined by ciliated epithelium extending into the lumen, as well as normal interstitial cells. There was an significant improvement in the histological composition of the epididymis in MECS treated rats relative to controls, so that (Figure 4, Section B, C, \& D) revealed derangement, shrinkage of interstitial cells, and dramatic changes in cellular integrity. When these MECS-treated groups were compared to the control groups, there was a biologically significant difference in the histological parts.

\section{DISCUSSION}

Several medicinal plants have been stated to have antifertility properties in India as well as other parts of the world. Medical historians have identified a number of plants with abortifacient, contraceptive, and emmenagogue properties. With this in mind, the aim of this study was to test whether MECS had an antisteroidogenic impact in male rodents.

Our earlier research on the phytochemical screening of methanol extracts of C. serratum revealed the presence of carbohydrates, flavonoids, tannins, sterols and terpenoids. As per the OECD guideline 420 (acute oral toxicity-Acute Toxic Class
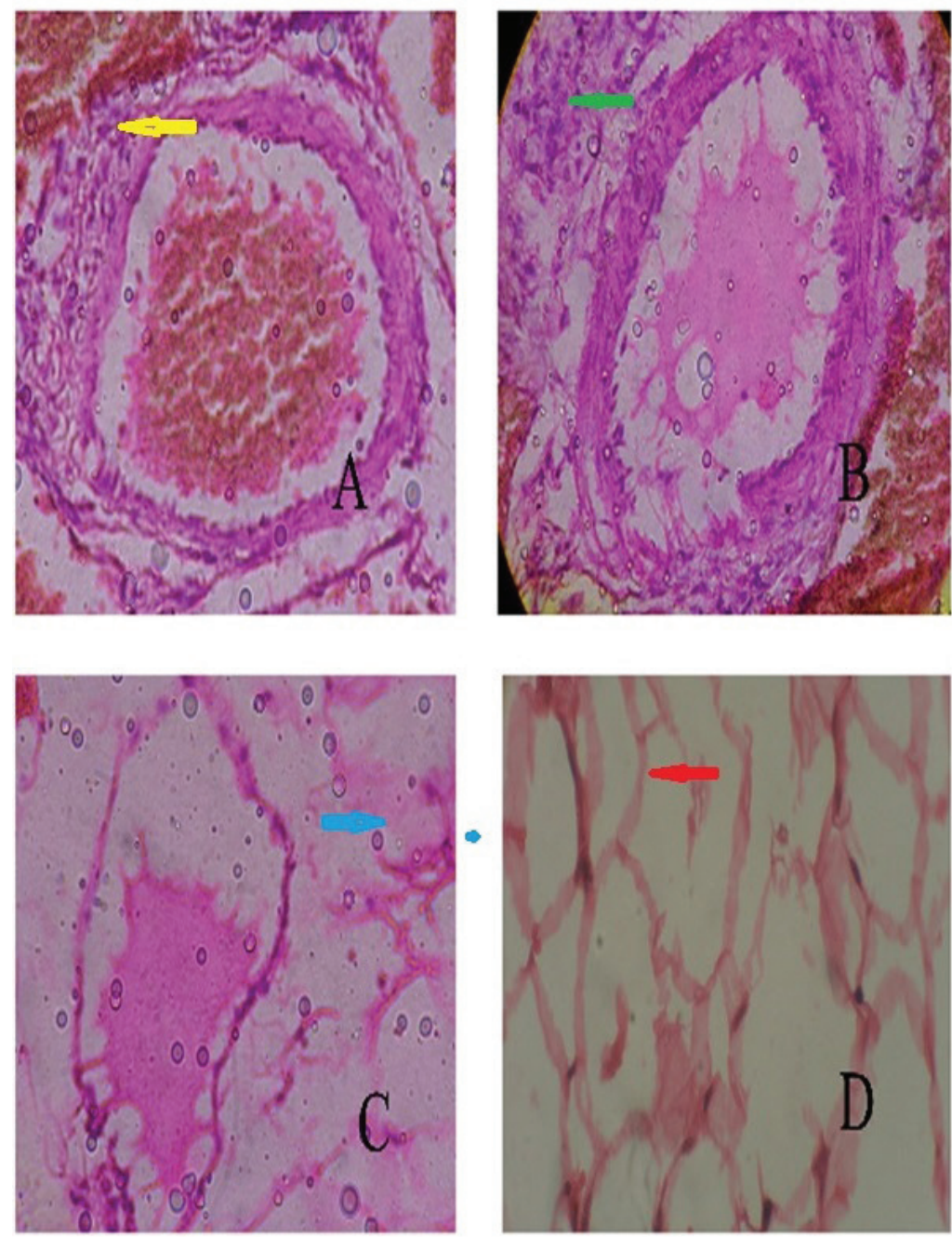

Figure 4. Effects of MECS on histological structure of rat epidydimis

Section A. Control, Distilled water (10 ml kg-1 b.wt. p.o.) showed the normal interstitial cells (Yellow arrow). Section B. MECS (100 mg kg-1 b.wt. p.o.) exhibited the derangement of interstitial cells (Green arrow). Section C. MECS (300 mg kg-1 b.wt. p.o.), the shrinkage of interstitial cells (Blue arrow) was present. Section D. MECS (500 $\mathrm{mg} \mathrm{kg}^{-1}$ b.wt. p.o.) showed the drastic changes in the cellular integrity (Red arrow). 

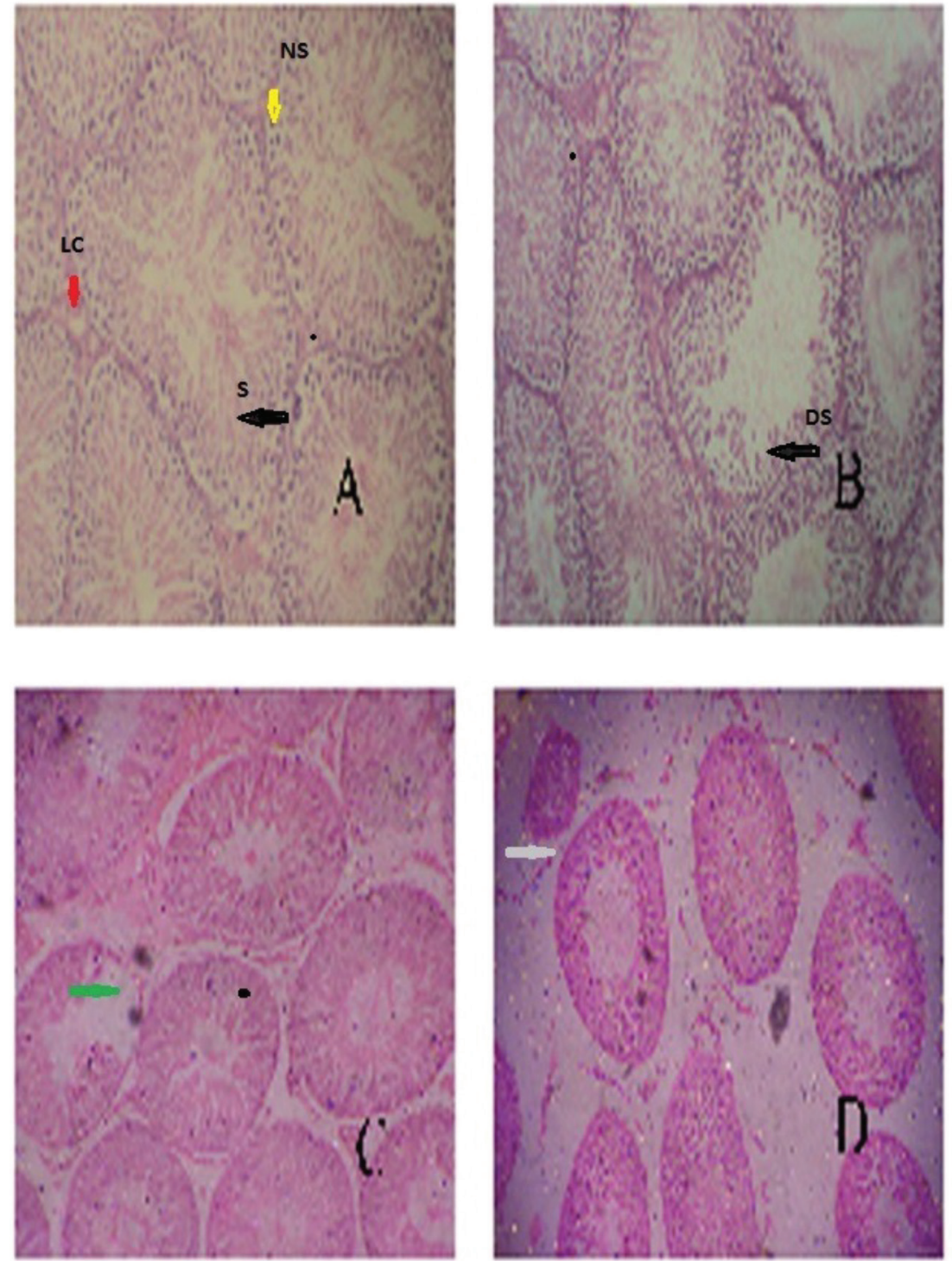

Figure 4. Effects of MECS on histological structure of rat testis.

Section A. Control, Distilled water (10 ml kg-1 b.wt. p.o.) showed the normal arrangement of sertoli cells (Black arrow), spermatogonia (yellow colour) and leydig cells (Red arrow). Section B. MECS (100 mg kg-1 b.wt. p.o.) showed the distorted seminiferous tubule (Black arrow). Section C. MECS (300 $\mathrm{mg} \mathrm{kg}^{-1}$ b.wt. p.o.) exhibited the disorganized population of spermatogenic cells (Green arrow). Section D. MECS (500 mg kg-1 b.wt. p.o.) the Spermatocytes within the lumen are very few with evidence of reduction spermatogenesis, showing severe hypercellularity of leydig cells (Grey arrow).

Method) the acute toxicity of plant of C. serratum was reported this plant extract was not not cause lethal to the male rats even at the dose of $2000 \mathrm{mg} \mathrm{kg}^{-1}$ b.wt (Sarathchandiran, Kadalmani, \& Navaneetha Krishnan, 2014 b).

The anti-fertility effect of MECS was confirmed by the following measures. A great decline in the weights of testis, epididymis and seminal vesicle were observed in all treatment groups when compared with the control. Reduction of reproductive organ weights, the disintegration of Leydig cells and regressive degenerative changes in testis, vas deferense, and epididymis indicated the anti-androgenic activity (Hiremath, Badami, Swamy, Londonkar, \& Patil, 1997).

In the androgenic pathway, cholesterol and ascorbic acid are essential principle precursors for the formation of androgen in testis. This is involved in the process of steroidogenesis in rat testis (Rajnish et al., 2011; Sharma \& Jacob, 2001). Feronia limonia fruit pulp extract-treated rats show impairment of spermatogenesis due to an accumulation of cholesterol and ascorbic acid in rat testis (Dhanapal, Ratna, Sarathchandran, \& Gupta, 2012). Mycotoxin MT81 and its benzoylated derivative induced an increased level of testicular cholesterol and ascorbic acid in male mature rats leading to impaired spermatogenesis (Choudhury, Gupta, \& Majumder, 2011). The present study showed an elevated level of cholesterol and ascorbic acid in MECS treated rats testicular tissues, indicating the impaired spermatogenesis.

In our earlier studies, the MECS showed a reduction in sperm count and their motility. This indicates the inhibition of testosterone synthesis (Sarathchandiran, Kadalmani, \& Navaneetha 
Krishnan, 2014a). This theory was reinforced by changes in cholesterol and ascorbic acid, and it is further supported by the decreased importance of G-6-PD and $\Delta^{5}-3 \beta-H S D$ activities in testicular tissues. G-6-PD and 5-3ß-HSD have been successively identified to form two major androgen biosynthesis enzymes. The synthesis of androgen, based on the G-6-PD and $\Delta^{5}-3 \beta-H S D$ enzyme on Knorr's well-documented knowledge. The suppressed steroid activity of the testicles could prevent cholesterol from being converted into testosterone by damaging the activities of these two basic androgen-based enzymes. (Anuja, Nithya, Rajamanickam, \& Madambath, 2010; Pankajakshy \& Madambath, 2009).

The decrease in Leydig cells observed in the histological structure of rat testis may be correlated with decreased testosterone production (Eik-Nes, 1970). Diminution of testosterone levels may indicate the delayed maturation of spermatozoa and the lower FSH and LH levels may affect the Sertoli cell function present in the seminiferous tubules resulting in the disturbing facilitatory function of these cells. The testosterone surge is required to stimulate the accessory glands fully. Decreased endogenous testosterone secretion from the testis deprive the development of mature sperm and also it suppresses testicular steroidogenesis and spermatogenesis (Kusemiju, Osinubi, Noronha, \& Okanlawon, 2010). The fructose contents in seminal vesicles and epididymal protein were shown to be significantly $(p<0.05)$ reduced in all doses of MECS treated rats. Fructose and citric acid play an essential role in sperm motility and concentration, especially with regards to energy metabolism (Videla, Blanco, Galli, \& Fernández-Collazo, 1981). Fructose is a fundamental sugar in semen. Sperm motility and sperm count were diminished in aluminum chloride treated rats due to an absence of fructose content in seminal vesicles of mice (Chinoy \& Ranga Geetha, 1984). The protein level is directly associated with the secretory activity of epididymis, which in turn depends on the androgen levels (Jones, 1977).

The antisteroidogenic property findings are additionally upheld by histopathological changes in the testicles. Leydig cells were lessened which demonstrates the inadequacy of these cells to synthesize testosterone. The quantity of Leydig cells has an immediate bearing on spermatogenesis (Gupta, Kumar, Dixit, \& Dobhal, 2000). The reduction in the number of secondary spermatocytes and spermatids may be due to an insufficient amount of testosterone (De Kretser \& Kerr, 1994). Distorted epithelial layer patterns and pyknosis were observed among the epithelial cells. The interstitial spaces were filled with loose connective tissue (Vengaiah, Govardhan, \& Changamma, 2015). Ethanolic extract of C. papaya seeds on the epididymal histology revealed changes such as vacuolation in the tubules, loose contacts of the principal cells in the epithelium of epididymis and presence of degenerated late spermatids (Madan, 2013). Similar findings were observed in MECS treated animal testes such that a reduced number of secondary spermatocytes, spermatids and Leydig cells with changes of epididymal cellular integrity were eliciting adverse histological damage in the testes and epididymis. As per the previous reports, in rabbits, intravaginal administration of 0.5 mg $\beta$-sitosterylsulphate in KY jelly reduced pregnancy rates
(Burck, Thakkar, \& Zimmerman, 1982). Chronic administration of $\beta$-sitosterol at doses ranging from 50 to $500 \mathrm{pg}$ triggered testicular lesions and prevented the process of spermatogenesis in males (Ghannudi, Shareha, Elsamannoudy, Ibrahim, \& Elmougy, 1978; Malini, 1987). Based on the information presented above, we concluded that $\beta$-sitosterol plays an important role in male anti-fertility.

\section{CONCLUSION}

In conclusion, the testicular steroidogenesis and fertilities were lower in the MECS-treated rats, and anti-androgenic results were reported in hormonal study. Furthermore, histopathological findings confirmed the drug's male contraceptive function. More research is needed to determine the antifertility effect of MECS in various animal species, as well as to identify the bioactive principles responsible for this effect and to comprehen the cellular behavior's underlying mechanism.

Peer-review: Externally peer-reviewed.

Ethics Committee Approval: This study was approved by the Institutional Animal Ethics Committee (IAEC) of the institute (No. SRCP/ IAEC/B.Pharm. Project /01/2016-17).

Author Contributions: Conception/Design of Study- N.K.S., N.G.R.; Data Acquisition- S.V., J.R.; Data Analysis/Interpretation- P.G., K.E., S.S.; Drafting Manuscript- K.E., S.S., N.K.S.; Critical Revision of ManuscriptN.G.R.; Final Approval and Accountability- N.K.S., N.G.R., K.E., S.V., J.R., P.G., S.S.

Conflict of Interest: The authors have no conflict of interest to declare.

Financial Disclosure: Authors declared no financial support.

Acknowledgement: Authors prefer to thank the management of Sree Vidyanikethan College of Pharmacy for providing a research facility for this work.

\section{REFERENCES}

- $\quad$ Auletta, F. J., Caldwell, B. V., \& Hamilton, G. L. (1979). Androgens: testosterone and dihydrotestosterone. Jaffe BM Behrmann HR (eds). Methods of hormone radioimmunoassay. Academic Press New York. 715-726.

- $\quad$ Anuja, M. N. M. K., Nithya, R. M. S. A., Rajamanickam, R. \& Madambath I. (2010). Spermatotoxicity of a protein isolated from the root of Achyranthesaspera: a comparative with gossypol. Contraception, 82(4), 385-390.

- $\quad$ Burck, P. J., Thakkar, A. L., \& Zimmerman, R. E. (1982). Antifertility action of sterol sulphate in the rabbit. Journal of Reproduction and Fertility, 66, 109-112.

- Chinoy, N. J., \& Ranga Geetha, M. (1984). Effects of Carica papaya seed extracts on the physiology of the vas deferens of albino rats, Acta Europaea Fertilitatis, 15(1), 59-65.

- $\quad$ Choudhury, S. M., Gupta, M., \& Majumder, U. K. (2011). Toxicological potential of mycotoxin MT81 and its benzoylated derivative on testicular spermatogenesis and steroidogenesis in mature male Wistar albino rats. Toxicology Mechanisms and Method, 21, 426-433.

- $\quad$ Dhanapal, R., Ratna, J. V., Sarathchandran, I., \& Gupta, M. (2012). Reversible antispermatogenic and antisteroidogenic activities of Feronia limonia fruit pulp in adult male rats. Asian Pacific Journal 
of Tropical Biomedicine, 2(9), 684-690.

- De Kretser, D. M, \& Kerr, J. B. (1994). The cytology of the testis, in The Physiology of Reproduction, Knobil, E. and Neill, J. D., Editors. Raven Press: New York. p. 1177-1290.

- $\quad$ Eik-Nes, K.B. (1970). Synthesis and Secretion of androstendione and tesosterones. In:The Androgens of the Testis (K.B. Eik-Nes, Ed) New York.

- Ghannudi, S. A., Shareha, A. M., Elsamannoudy, F. A., Ibrahim, H. A., \& Elmougy, S. A. (1978). Adverse effects of phytoestrogen. 1: Histological and histochemical effects of flsitosterol in testis of immature male rabbits. Libyan Journal of Science, 8, 17-24.

- Gupta, R. S., Kumar, P., Dixit, V. P., \& Dobhal, M. P. (2000). Antifertility study of the root extracts of the BarleriaprionitisLinn. In male albino rats with special reference to testicular cell population dynamics. Journal of Ethnopharmacology, 70(2), 111-117.

- Hayat, M. A. (1981). Principles and Techniques of Electron Microscopy. Biological Applications, $2^{\text {nd }}$ ed., Vol. 1. Baltimore: University Park Press.

- Hamilton, D. W. (1975). Structure and function of the epithelium lining the ductuliefferentes; ductus epididymis and ductus deferens in the rat. In: Handbook of Physiology. Washington D.C., American Physiological Society (Hamilton, D. W. \& Greep, R. O. volume editors). 5, 259-301.

- Hiremath, S. P., Badami, S., Swamy, H. K. S., Londonkar, R. L., \& Patil, S. B. (1997). Anti-androgenic effect of Striga orobanchioides. Journal of Ethnopharmacology, 56(1), 55-60.

- Jones, R. (1977). Effects of testosterone, testosterone metabolites and anti-androgens on the function of the male accessory glands in the rabbit and rat. Journal of Endocrinology, 74(1), 75-88.

- Joshi, S. C., Sharma, A., \& Chaturvedi, M. (2011). Antifertility potential of some medicinal plants in males: an overview. International Journal of Pharmacy and Pharmaceutical Sciences, 3(5), 204-217.

- $\quad$ Khare, C. P. (2007). Indian medicinal plants: An illustrated Dictionary. New York, Springer.

- $\quad$ Kusemiju, T. O., Osinubi, A. A., Noronha, C. C., \& Okanlawon, A. O. (2010). Effect of aqueous extract of the bark of Carica papaya on the testicular histology in Sprague- Dawley rats. Nigerian Quarterly Journal of Hospital Medicine, 20(3), 133-137.

- Lohr, G. W., \& Waller, H. D. (1974). Glucose-6-phosphate dehydrogenase. Methods of Enzymology Analysis, 2, 636-643.

- Lowry, O. H., Rosenbrough, N. J., Farm, A. L., \& Randall, R. J. (1951). Protein measurement with Folin Phenol reagent. The Journal of Biological Chemistry, 193(1), 265-275.

- Madan, Z. (2013). Effect of ethanol extract of Carica papaya seeds on the histology of the epididymis of adult male albino mice. International Journal of Scientific and Research, 3, 1-5.

- Malini, T. (1987). Effecrs of fi-Sitosterol on Reproductive Tissues of Male and Female Albino Rats. Doctoral thesis, University of Madras, India.

- $\quad$ Singh, M. K., Khare, G., lyer, S. K Sharwan, G \& Tripathi, D. K. (2012). C. serratum: A clinical approach. Journal of Applied Pharmaceutical Science, 2(2): 11-15.

- $\quad$ Omaye, S. T., Turnbull, J. D., \& Souberlich, H. E. (1979). Selected methods for the determination of ascorbic acid in animal cells, tissues, and fluids, in: McCormick, D.B., Wright, L.D. (Eds.), Methods in Enzymology, New York, Academic Press; 3-11.

- $\quad$ Padashetty, S. A., \& Mishra, S. H. (2007). Effects of terpenoidal fraction of Echinopsechinatus roots onreproductive parameters of male rats. Journal of Natural Medicines, 61, 452-457.
- Pandey, A., \& Tripathi, S. (2014). Concept of standardization, extraction, and pre-phytochemical screening strategies for herbal drug. Journal of Pharmacognosy and Phytochemistry, 2, 115-119. Pankajakshy, A., \& Madambath, I. (2009). Spermatotoxic effects of Cananga odorata (Lam): a comparison with gossypol. Fertility and Sterility, 91(5), 2243-2246.

- Pokharkar, R. D., Saraswat, R. K., \& Kotkar, S. (2010). Survey of plants having antifertility activity from Western Ghat area of Maharashtra state. Journal of Herbal Medicine and Toxicology, 4(2), 71-75.

- Rabin, B.L., Leipsner, G., \& Deane, H.W. (1961). A rapid, sensitive assay procedure for adrenal steroid-3 beta-ol-dehydrogenase activity. Endocrinology, 69, 619-625.

- Rajnish, G., Kachhawa Jai, B. S., Gupta, R. S., Kumar, S. A., Sharma, M.C., \& Dobhal, M. P. (2011). Phytochemical evaluation and antispermatogenic activity of Thevetia peruviana methanol extract in male albino rats. Human Fertility, 14(1), 53-59.

Sarathchandiran, I., Kadalmani, B., \& Navaneetha Krishnan, S. (2014a). Evaluation of spermatotoxic activity of C. serratum in male albino rats. International Journal of Biological \& Pharmaceutical Research, 5(1), 16-21.

Sarathchandiran, I., Kadalmani, B., \& Navaneetha Krishnan. S. (2014b). Preliminary phytochemical study and safety profile of C. serratum. International Journal of Phytopharmacology, 5(3), 172-178.

- Savadi, V., Alagawadi, K. R. (2009). Antifertility activity of ethanolic extracts of Plumbagoindica and Aervalanata on albino rats. International Journal of Green Pharmacy, 3, 230-233.

- Sharma, N., \& Jacob, D. (2001). Antifertility investigation and toxicological screening of the petroleum ether extract of the leaves of Mentha arvensis L. in male albino mice. Journal of Ethnopharmacolology, 759(1), 5-12.

- Setty, B. S., Kamboj, V. P., \& Khanna, N. M. (1977). Screening of Indian plants for biological activity. Part VII. Spermicidal activity of Indian Plants. Indian Journal of Experimental Biology, 15(3), 231-232. Singh, M. K., Khare, G., lyer, S. K., \& Tripathi, D. K. (2012). C. serratum: A Clinical approach. Journal of Applied Pharmaceutical Science, 2(2), 11-15.

- $\quad$ Sperry, W. M., \& Webb, M. A. (1950). Revision of schoenheimersperry method for cholesterol determination. The Journal of Biological Chemistry, 187(1), 97-106.

Umadevi, M., Kumar, P. S., Bhowmik, D., \& Duraivel, S. (2013). Medicinal plants with potential antifertility activity. Journal of Medicinal Plants Studies, 1(1), 26-33.

Vengaiah, V., Govardhan, N. A., \& Changamma, C. (2015). Histomorphological Evaluation of Reproductive Organs Following Piper betel (Linn.) Leaf Stalk Extract Administration in Male Albino Rats. British Journal of Pharmaceutical Research, 5, 181-191.

Videla, E., Blanco, A. M., Galli, M. E., \& Fernández-Collazo, E. (1981). Human seminal biochemistry: fructose, ascorbic acid, citric acid, acid phosphatase and their relationship with sperm count. Andrologia, 13(3), 212-214.

- World Health Organization. (1983). A method for examination of the effect of plant extracts administered orally on the fertility of male rats. APF/IP, 99/4E, MB-50, 1-12. 